\title{
Research Note \\ ENCORE AND PIXIE, TWO LATE-SEASON MANDARIN HYBRIDS IN PUERTO RICO ${ }^{1}$
}

Encore and Pixie are late-maturing mandarin hybrids originated at the Citrus Research Center of the University of California. ${ }^{2}$ Certified virusfree budwood of these hybrids was received by the author from Dr. James W. Cameron during 1966. The material was grafted on Cleopatra mandarin and planted at the Adjuntas Substation (lat. $18^{\circ} 11^{\prime}$ N., long. $66^{\circ} 48^{\prime}$ W.; el. $558 \mathrm{~m}$ ) for observation under the prevailing conditions of the region. The soil is an Orthoxic Tropohumults (clayey, oxidic, isohyperthermic). Average rainfall is around $1,900 \mathrm{~mm}$, and maximum and minimum temperatures are around $28^{\circ}$ and $15^{\circ} \mathrm{C}$.

Both hybrids have an unusually late maturing season that is suitable for the fresh market in Puerto Rico.

Encore mandarin is a cross between King (Citrus nobilis Lour) and Willow Leaf mandarin (Citrus reticulata Blanco) ${ }^{2}$. Fruit ripens from May to June usually remaining in good condition until August. Fruit shape is strongly oblate, with little or no neck. Transverse fruit diameter is about 5 to $7 \mathrm{~cm}$ and height varies from 3 to $5 \mathrm{~cm}$.

Pixie is a second-generation hybrid from open pollination of $F_{1}$ hybrid Kincy $^{2}$. The latter is a cross between King and Dancy tangerines (Citrus reticulata Blanco). Fruit at Adjuntas ripens at approximately the same time as Encore. Fruit diameter varies from 3.5 to $6.0 \mathrm{~cm}$, but is very variable even in the same tree. In Adjuntas the fruits are seedless even though cross pollination may occur with other citrus cultivars in a nearby citrus collection.

Juice from these two mandarins was analyzed on May 11, 1977 with the following results

\begin{tabular}{lcc}
\multicolumn{1}{c}{ Hybrid } & $\begin{array}{c}\text { Citric Acid } \\
\text { Mg/ } 100 \mathrm{ml}\end{array}$ & Brix \\
Pixie & 696 & 14.4 \\
Encore & 1310 & 22.3
\end{tabular}

Both hybrids could be used for the production of off-season mandarins. Color, flavor, and general appearance of the fruits are excellent at Adjuntas even though the effect of climate on rind color, quality, and ripening is noticeable. Perhaps some other areas of the Island may be more favorable for these late-hybrids. Pixie could be an ideal fruit tree for home gardens because of its seedlessness.

Jaime E. Jordán Molero

Agronomy and Soils Department

\footnotetext{
${ }^{1}$ Manuscript submitted to Editorial Board November 1, 1977.

${ }^{2}$ Cameron, J. W., Soost, R. K., and Frost, H. B., 1965. Encore and Pixie ... two mandarin hybrids with unusually late seasons of use. Calif. Agric. Exp. Stn., Div. Agric. Sci., Univ. Calif. Bull. 814.
} 